\title{
車椅子使用者が混在する群集の流動特性に関する研究 WALKING BEHAVIOR OF A CROWD INCLUDING WHEELCHAIR USERS
}

\author{
土屋伸一*, 古川容子*, 宮野義康**, 吉田 直 之**, 長谷見 雄二*** \\ Shin'ichi TSUCHIYA, Yoko FURUKAWA, Yoshiyasu MIYANO, \\ Naoyuki YOSHIDA and Yuji HASEMI
}

\begin{abstract}
The purpose of this study is to grasp the flow characteristics of a crowd including wheelchair users through experiments. The results show that the walking speed of the wheelchair users in the crowd tend to increase rather than decline, and the density of the crowd varies with whether people without disabilities pass the wheelchair users or not. The arrangement of the wheelchair users has a great effect on the walking speed of the crowd. Based on above results, the walking speed and flow coefficient of a crowd including the wheelchair on which the abled ride are presented for evacuation planning.
\end{abstract}

Keywords: Fire safety, Evacuation, Crowd, Wheelchair, Walking speed, Flow coefficient, 防火，避難，群集，車椅子，歩行速度，流動係数

\section{1. はじめに}

\section{1 研究の目的}

「高齢者・身体障害者等が円滑に利用できる特定建築物の建築の 促進に関する法律」（通称：ハートビル法）の制定に伴い、不特定 多数が利用する建築物では、利用者は健常者だけとは限らず、非常 時の避難において、群集内に健常者と車椅子使用者などが混在する 可能性が高くなってきている。また、2000年 6 月には建築基準法が 改正され、避難規定の一部に性能規定が導入されたが、病院や社会福 祉施設など自力避難困難者が多い建築物については、在館者の避難特 性を予測し難いとして国土交通省告示避難安全検証法の適用から外さ れ、性能設計の道は当面ふさがれた状況にある。

従来、避難設計に用いられている歩行速度, 流動係数等のデータ は主に戸川文川の研究によるものであり、駅施設や劇場等の出入口 における群衆の観察から導きだされたものである。その他に歩行速 度, 流動係数等の既往研究には、戸川と同様、駅の通勤群衆を実測 したもの文213i゙あるが、いずれも健常者を対象としている。また、 車椅子等の歩行行動に関する既往の研究には、病院の入院患者を実 測したもの文1)などがあるが、単独歩行を対象としており、車椅子 使用者が健常者の中に混在した場合の群集歩行行動については解明 されていない部分が多く、研究事例も少ない。しかし、災害時の避
難行動を考えると、車椅子利用者の単独避難という状況は想像でき ず、一般には健常者と混在して避難すると考えられる。また、高齢 化社会の進行や車椅子でアクセス可能なバリアフリー建築の普及を 踏まえると、高齢者や車椅子使用者が混在する群集の流動特性を把 握し、避難設計に反映させることは緊急の課題である。

そこで本研究では、車椅子を使用した単独歩行及び健常者の中に 車椅子が混在した場合の群集流動について、健常者を使つた実験を 行い、車椅子使用者が混在する群集の歩行速度及び流動係数を把握 することを目的とする。

\section{2 健常者を車椅子利用被験者とする理由}

一概に車椅子使用者といっても、高歯者や病気の人、下肢障害は あるものの上半身は健常な人などさまざまである。しかし、本研究 では車椅子使用者が混在するときの群集流動への影響を把握するこ とが目的であり、また、従来、車椅子使用者の避難に関する実験 研究がほとんどなく、実際の身障者を被験者とした場合に起こり 得る安全管理上の問題点を把握できていないことなどを考慮し、 ここでは車椅子利用被験者も健常者とした。なお、その限界と実 際に身障者等を被験者とする実験への展望については、本実験結 果に基づいて後述する。

\footnotetext{
* 早稲田大学大学院理工学研究科 大学院生·工修

Graduate Student, Graduate School of Science and Engineering, Waseda University, M. Eng.

** 早稲田大学大学院理工学研究科 大学院生

*** 早稲田大学理工学部建築学科 教授. 工博

Graduate Student, Graduate School of Science and Engineering, Waseda University Prof., Department of Architecture, Waseda University, Dr. Eng.
} 


\section{2. 実験の概要}

\section{1 実験の方法}

早稲田大学理工学部建築学科の学生を被験者とした。実験は 2 年 生を対象とする実験授業注 11 を利用して行い、(1)車椅子使用時の単 独歩行、(2)車椅子使用者が混在する群集歩行という手順で行った。 また、群集歩行実験において車椅子に乗るのは、単独歩行実験にお ける車椅子使用時の歩行速度が遅かった者から選定した。なお、車 椅子は自走式注2)を使用した。

\section{2 車椅子使用者の単独歩行実験}

早稲田大学理工学部 55 号館の廊下を使用し、20 m の距離を歩行 したときの時間を計測した。歩行距離は建築基準法の重複距離の規 定及び実際の建物における居室から避難階段に至る一般的な歩行距 離を勘案し決定した。

\section{3 車椅子使用者が混在する群集歩行実験}

早稲田大学理工学部 55 号館のロビー空間に幅 $2 \mathrm{~m}$ の通路を設定 し、スタート地点に整列した状態から合図と共に一斉にスタート し、単独歩行実験と同様、20 mの距離を歩行したときの各個人の 歩行時間及びネック注引の通過時間等を計測した。通路幅について は、建築基準法の廊下幅の規定及び実際の建物における一般的な 廊下幅を勘案し決定した。実験は $2001 ， 2002$ 年度に実施したが、 一部の実験では歩行中の群集密度の変化を観測するために、ス タート直後とネック手前の範团 (各 $5 \mathrm{~m}^{2}$ ) をビデオ撮影した（図 1 参照)。また、車椅子の配置パターンの違いによる実験ケースを図 2 に示す。周りの健常者に影響を及ぼすのは、車椅子で通路がふ さがる場合と考えられるため、混在する車椅子使用者の数は 2 人 （混在率 $10 \%$ ）を上限とした。ネックはスタート地点から $10 \mathrm{~m} の$ 位置に設定し、ネックの位置の違いによる影響をみるために、ネッ クを通路中央と端に設定した。

\section{4 用語の定義}

本研究に使用される用語について、以下のとおり定義する。

列：群集の進行方向の列 ( $\mathrm{a}$ 列〜 $\mathrm{d}$ 列)

行：群集の進行方向に垂直な列（1行〜最大 7 行）

歩行速度 : 各被験者個人の歩行速度

群集速度：群集最後尾における最も遅い健常者の歩行速度泩》 通行量：単位時間、単位幅あたりの通過人数 (単位: 人 $/ \mathrm{m} / \mathrm{sec}$ ) 流動係数：扉等ネックの通過能力として定められる通行量泩 5 実験ケースの呼称:ケースAのパターン 1 であれば、「ケースA1」 被験者位置の呼称：a 列の 1 行目であれば、「a1」

\section{3. 実験結果}

\section{1 車椅子使用者及び健常者の単独歩行速度}

図 3 (a) に車椅子使用者の歩行速度のばらつきを表す箱ひげ図を 示す。被験者数は 110 人注6)であるが、事前に図 3 と同様の方法で 統計処理し、2 人のデータを外れ值拄7として除去した結果、108人 のデータを有効とした。これによると、歩行速度の最大值は 1.61 $\mathrm{m} / \mathrm{sec}$ 、最小值は $0.58 \mathrm{~m} / \mathrm{sec}$ 、平均值は $1.04 \mathrm{~m} / \mathrm{sec}$ 、標準偏差 は 0.25 であった。図 4 には歩行速度の度数分布を示す。これによ ると、車椅子使用者の場合は正規分布に比べて偏平で若干左に 寄うていることがわかる。このため、108人のデータから母平均の $\mathrm{t}$ 推定を実施したところ、信頼度 $95 \%$ で車椅子使用者の歩行速度

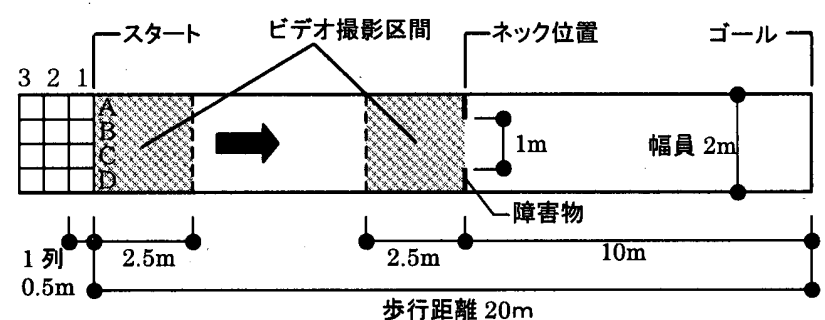

図 1 群集歩行実験の方法

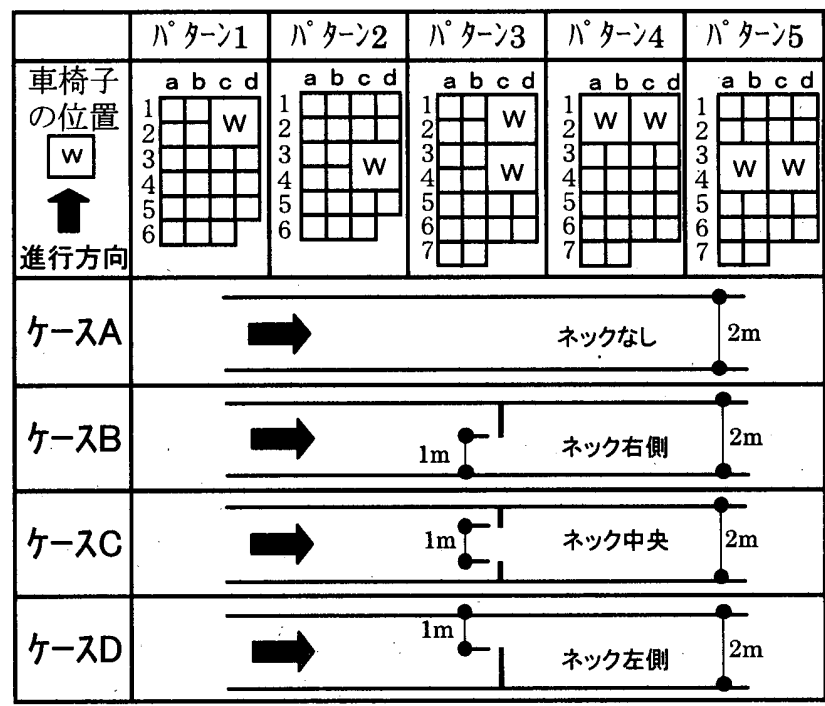

図 2 群集歩行の実験ケース

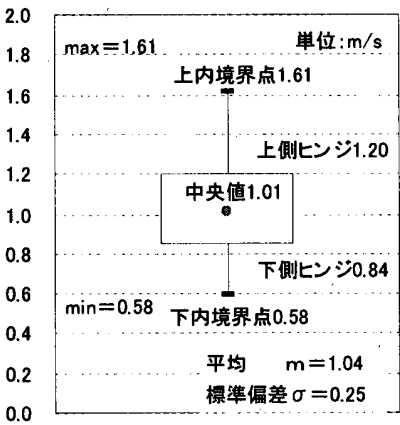

(a) 車椅子使用者

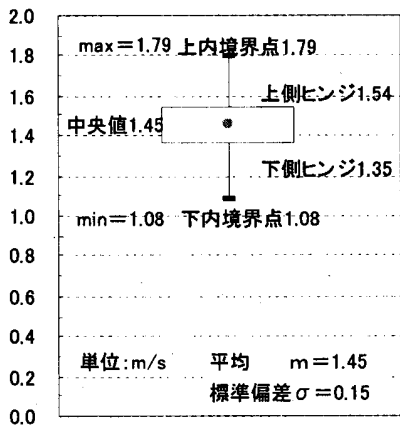

(b) 健常者
図 3 単独歩行速度のばらつき

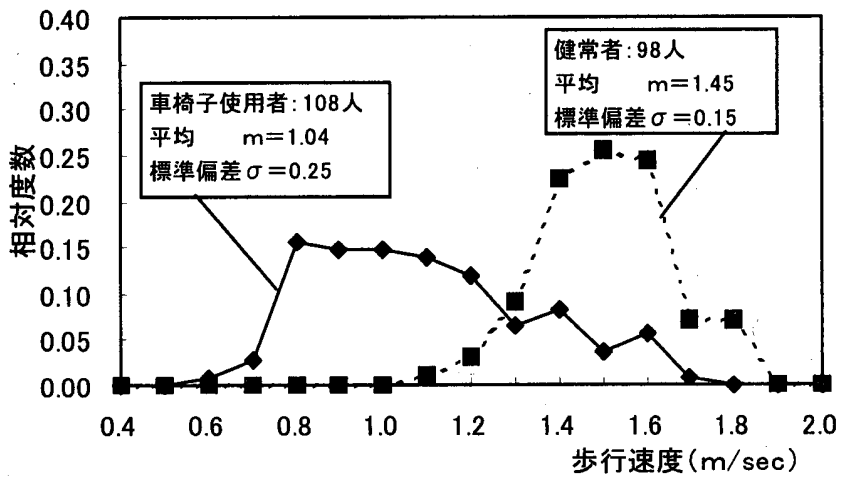

図 4 歩行速度の度数分布

の平均值は $0.85 〜 1.23 \mathrm{~m} / \mathrm{sec}$ の範䧃にあることがわかった。志 田等は病院の入院患者を刘象とする実測に基づき、自力歩行の車椅 子の単独歩行速度の代表值を、その平均値から標準偏差を引いた值 
で表して0.67 m/secと報告している文れ。この考え方に従い、今 回の歩行速度の平均値の下限から標準偏差を引いた值を求めると $0.6 \mathrm{~m} / \mathrm{sec}$ と志田等の報告値に近い値となる。

また、健常者についても車椅子使用者と同様に分析した結果、 110 人のうち 98 人のデータを有効とし、これから母平均の $\mathrm{t}$ 推定 を実施したところ、信頼度 $95 \%$ で健常者の歩行速度の平均は 1.25 〜 $1.65 \mathrm{~m} / \mathrm{sec}$ の範囲にあることがわかった。これにより、歩行速 度の平均値の下限から標準偏差を引いた值は $1.1 \mathrm{~m} / \mathrm{sec}$ となる。 (図 3 (b)，図 4 参照)。

\section{2 群集内の健常者及び車椅子使用者の歩行特性}

ネックがない場合 (ケースA) における健常者と車椅子使用者の 単独歩行時と群集歩行時の歩行速度の関係を、車椅子使用者の数. 配置別に表したものを図 5 (a)〜 (f) に示す。これによると、群集内 の車椅子使用者の歩行速度は、単独歩行に比べてほとんど低下せ ず、むしろ增加傾向にあることがわかる。これは、群集に混在する ことによって、車椅子使用者が周りの健常者にあわせようとする意 識が強く働いたためと考えられる。一方、健常者については、図 5 に示す対角線より右側の範囲にあり、群集になることによって歩行 速度は低下する傾向にあることがわかる。ここで、車椅子使用者が 並列しないパターン $1 \sim 3$ (図 5 (b)，(c)，(d)）では、車椅子使用 者より後続の健常者でも、車椅子使用者より速く歩行している者が おり、車椅子使用者が後続の健常者の歩行速度を決定的に規定して いないことがわかる。この原因としては、車椅子使用者により通路 がふさがれないため、健常者は車椅子使用者を追い越すことが可能 であったと考えられ、実験の模様を撮影した画像からもその傾向が 観察できた。

これに対し、車椅子使用者が並列するパターン 4,5（図 5 (e)， (f)）では、車椅子使用者より後続の健常者は、車椅子使用者より 遅く歩行しており、車椅子が後続の健常者の歩行速度を規定してい ることがわかる。この原因としては、車椅子により通路がふさがれ ることによる影響が大きいと考えられるが、パターン 5 では、車椅 子使用者に速度差が生じており、通路が完全にふさがれていないに もかかわらず、後続の健常者が車椅子使用者を追い越すことができ ていない。これは 2 台の車椅子周辺では、健常者は車椅子を回り込 むような行動をとらなければ追い越せなかったためと考えられる。

なお、健常者の歩行速度は、単独歩行時にはかなりばらつきを示 していたが、図 5 (a)に示すように、群集時は約 $1.2 \mathrm{~m} / \mathrm{sec}$ でほぼ 一定になっている。その後、群集時の歩行速度は車椅子の増加とと もに再びばらつきが大きくなるが、これは車椅子の追い越しができ るかどうかに由来すると考えることができる。

\section{3 群集歩行実験における行数}

ネックがない場合（ケースA）における車椅子の数・配置別の各 行の歩行速度を図 6 (a) 〜 (d) に示す。歩行速度は後方ほど遅くなる ため、群集の歩行速度として列後尾（6，7行目）に着目すると、 縦 6 行のケースAl（図6 (a)) では; 各列の歩行速度は約 $1.2 \mathrm{~m} /$ secに近づいているのがわかる。また、縦 7 行のケースA3（図 6 (b) ) では、ケースA1に比べてばらつきがみられるものの、後続に いくに従い歩行速度が低下する傾向がみられる。この傾向が顕著に 表れるのがケースA4（図 6 (c)）である。ケースA4では、車椅子 使用者が先頭に 2 人並列しており、歩行速度がやや速かった 1 後 方の c 3，c4が進行方向左側にでてalを追い越した以外は追い越し が生じておらず、歩行速度低下の影響が後尾に伝播したと考えられ る。このため、b列の 7 行目以外、6，7 行目にかけて歩行速度は 約 $1.1 \mathrm{~m} / \mathrm{sec}$ に近づいているのがわかる。

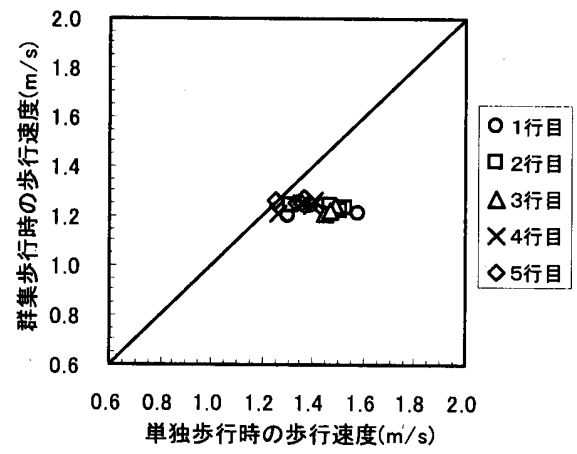

(a) パターン0（莗椅子混在なし）

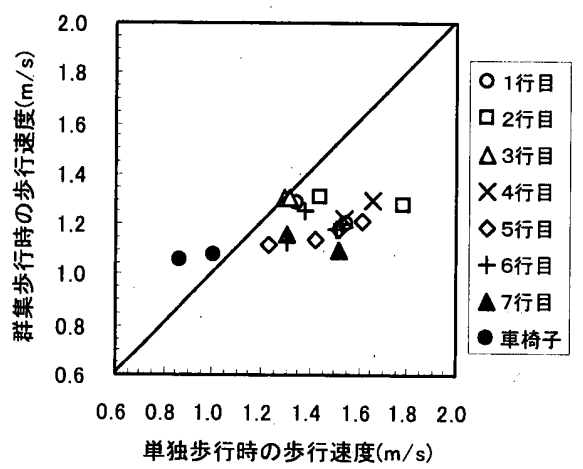

(d) パターン 3

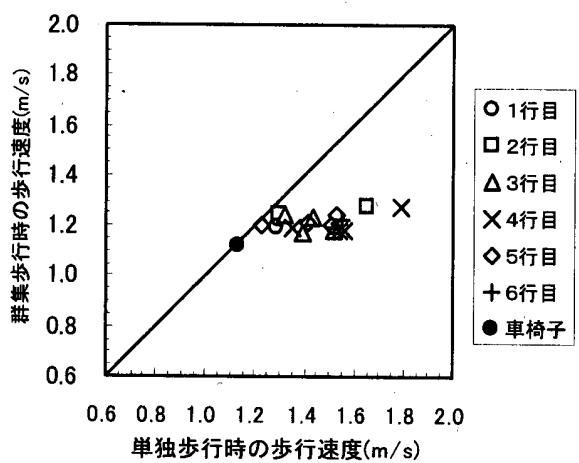

(b) パターン 1

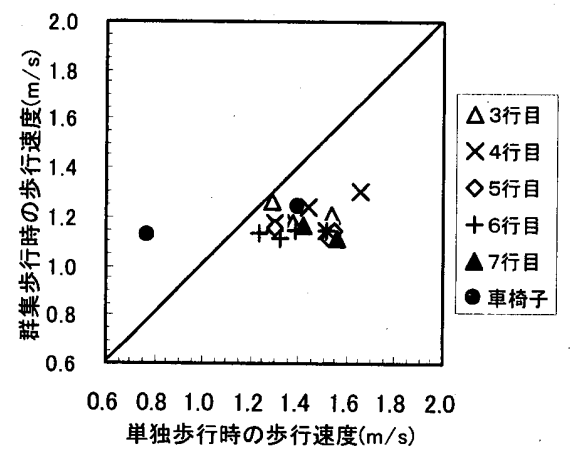

(e) パターン 4

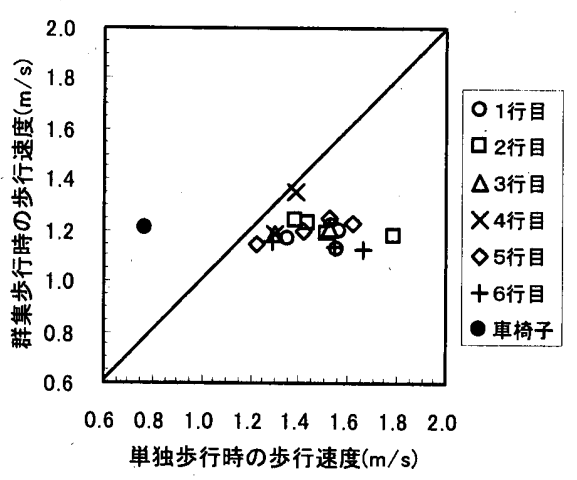

(c) パターン 2

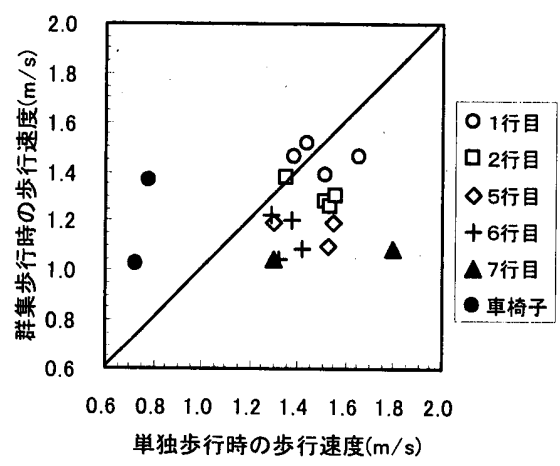

(f) パターン 5

図 5 ネックがない場合（ケースA）の単独歩行と群集歩行との関係 
一方、車椅子使用者より後続の行数が少ないケースA5（図 6 (d)) では、 $a, b$ 列とも 6 行目から 7 行目にかけてさらに歩行速度が低 下しているが、これは3.2 項で述べたように、車椅子使用者に速度 差が生じ通路が完全にふさがれていないにもかかわらず、2 台の車 椅子周辺では、健常者は車椅子を回り込むような行動をとらなけれ ば追い越せなかったために、歩行速度低下の影響が後尾に伝播した ものと考えられる。

以上のことから、車椅子使用者によって通路がふさがれない場 合には、健常者の歩行行動に及ぼす影響は比較的小さいが、車椅 子使用者が並列し、通路をふさいでしまう場合には、後続の健常 者の歩行速度に及ぼす影響が高くなること、また、避難設計に有 効な群集速度を得るためには、健常者の列では 6 行以上配置して、 行列後方の歩行速度の近似值が得られるようにする必要があると 考えられる。

\section{4 測定区間中央付近の群集密度の時間变化}

パターン $1,3 ４, 5$ について、ネック手前となる測定区間中央付 近の群集密度の時間変化を図 7 (a) 〜 (d) に示す。時間軸の 0 秒の 位置は、図 1 に示すように先頭がビデオ撮影区間の入口（スター 卜地点から $7.5 \mathrm{~m}$ の距離) に到着した時点としている。車椅子使用

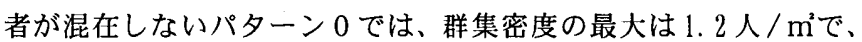
通過時間は他のどのケースよりも短くなっている。次にネック通 過時間が短いのは、車椅子の配置に関係なくネックがない場合 (ケースA）であるが、ネックがある場合（ケース B 〜 D ）の密度 変化は、パターンごとに似た性状を示しており、ネックがある場 合はその位置よりも、車椅子の数・配置が群集行動特性に及ぼす 影響が顕著であることがわかる。その中で、車椅子使用者が行列途 中に 2 人並列した場合（パターン 5 ）は、図 7 (d)に示すように、 群集が二つに割れたことで、車椅子の配置が異なるパターン 3,4 に 比べて全体的に群集密度は低い傾向にある。また、車椅子使用者が 2 人直列した場合 (パターン 3 ) は、図 7 (b) に示すように、先頭 到着後初期は、車椅子の混在率に関倸なくパターン 1 と似た性状を 示しているが、ネックがある場合（ケース B D D) は 8 秒前後から 群集密度が増加し、ネック通過も停滞している。これは、パターン 1 のように車椅子使用者が 1 人ならば健常者は追い越しが可能で あったものが、車椅子使用者が 2 人值列すると、追い越しが容易で なくなり、ネックの有無の影響が増大すること、また、ケース B で の遅滞が特に大きいことからみて、ネックと車椅子の位置関係の影. 響も顕著になると考えられる。

\section{5 群集速度と群集密度の関係}

ネックがない場合（ケースA）について、測定区間中央付近の密 度注8) と群集速度の関係を表したものを図 8 に示す。車椅子の数・配

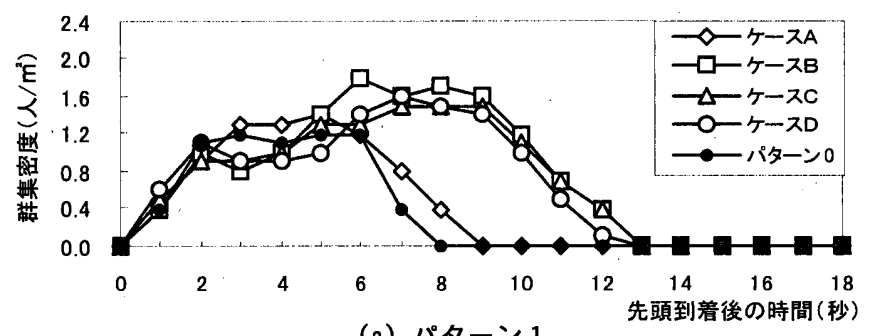

(a) パターン 1

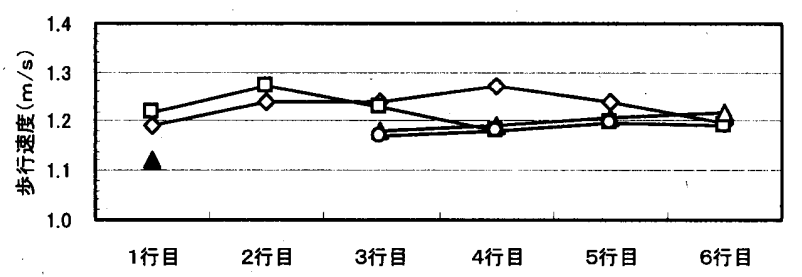

(a) ケース A1

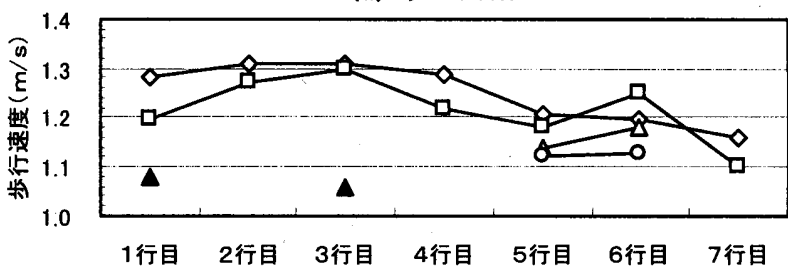

(b) ケース $A 3$

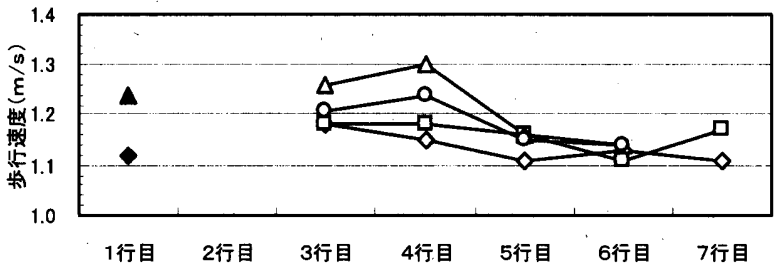

(c) ケース A4

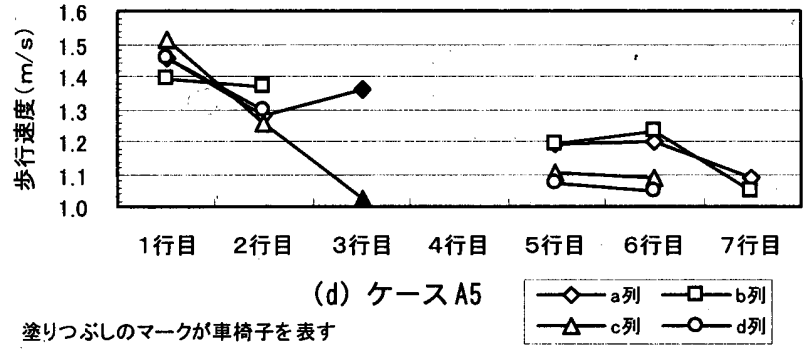

図 6 配置パターン別の各列の歩行速度
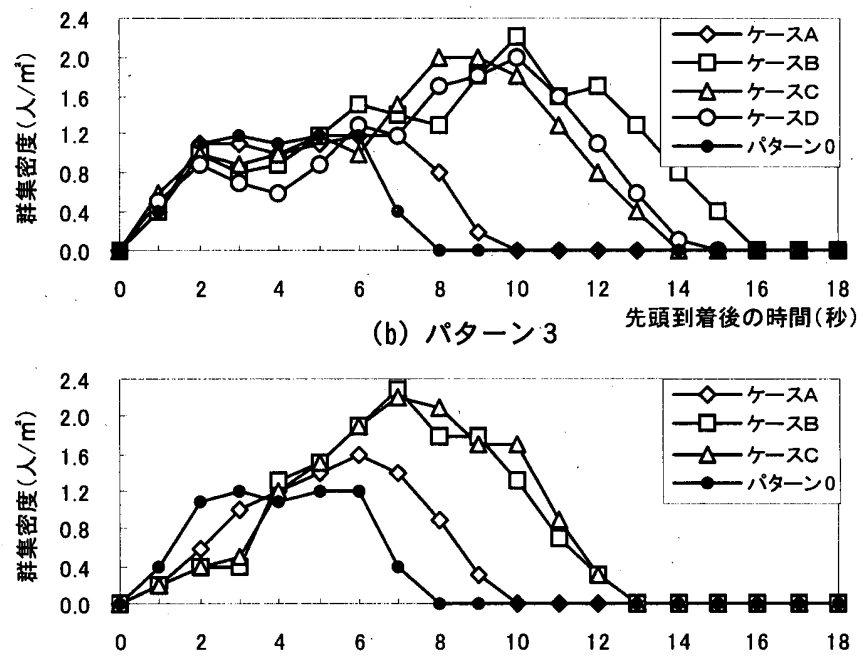

(c) パターン 4

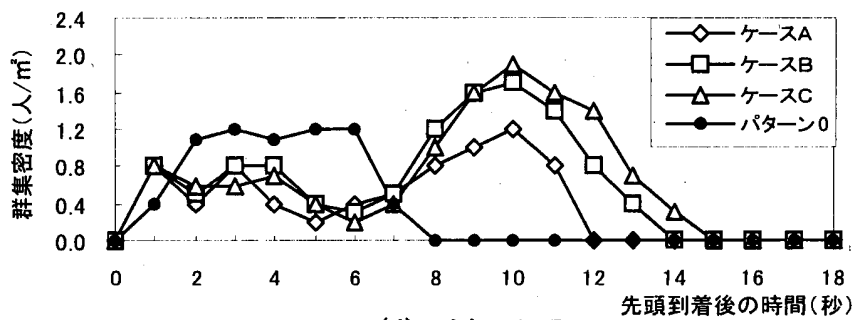

(d) パターン 5

図 7 測定区間中央付近の群集密度の時間変化 


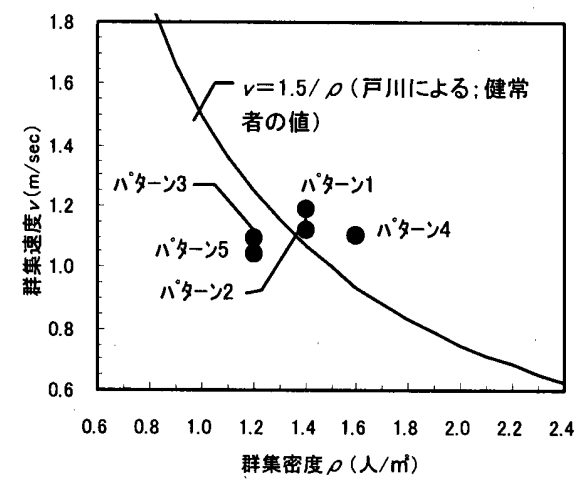

図 8 ネックがない場合（ケースA）の 群集密度と群集速度との関係

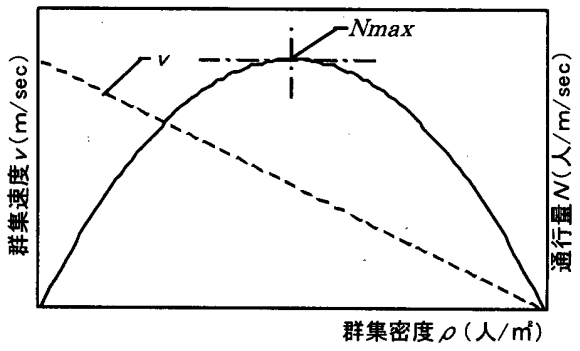

図 9 群集密度と速度, 通行量の関係文9

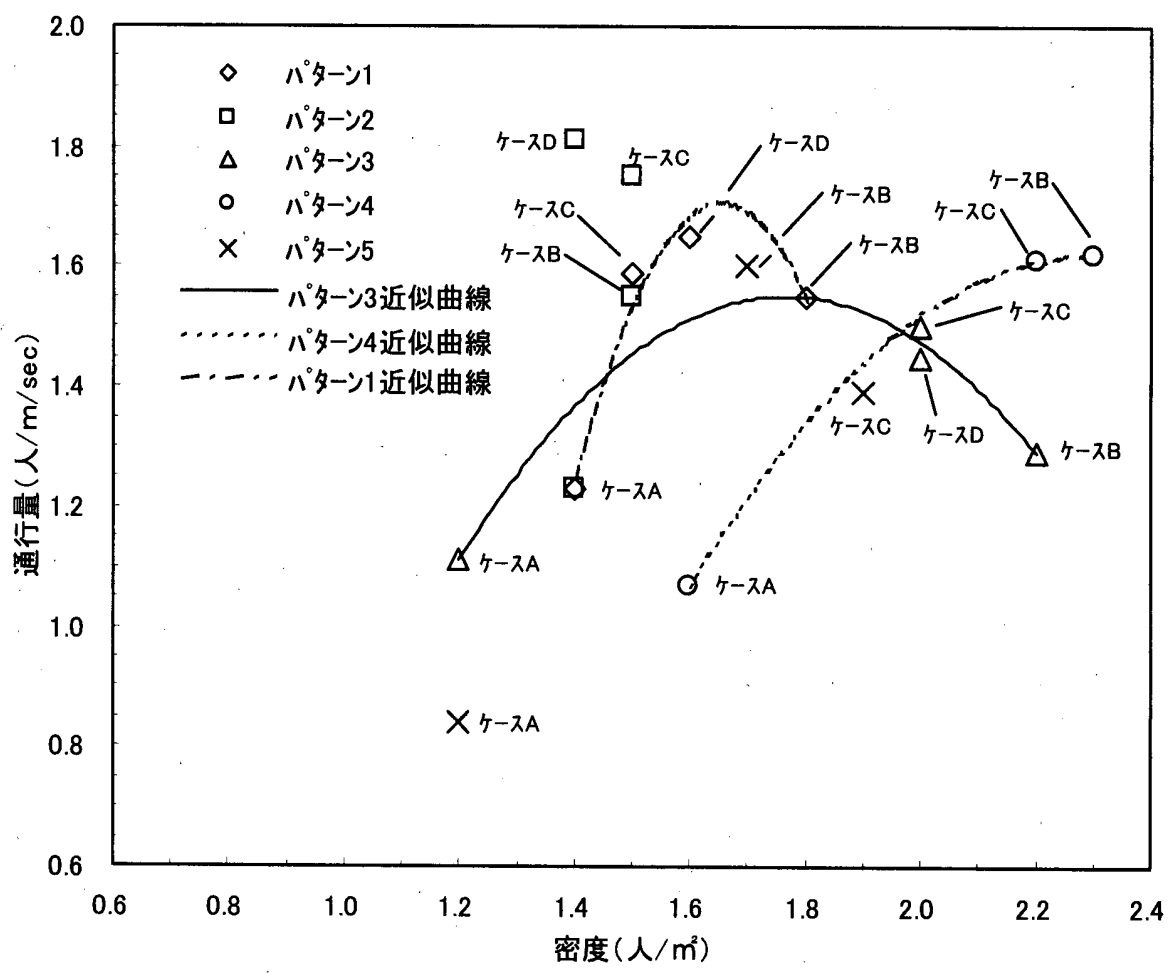

図10 ネック手前の群集密度と通行量との関係
置によって差はあるが、今回の実験では密度 $1.2 \sim 1.6$ 人/m範 囲で、その時の群集速度は $1.05 \sim 1.2 \mathrm{~m} / \mathrm{sec}$ であった。スタート 時の密度は約 3 人 $/ \mathrm{m}^{2}$ であるから、ほぼ半分に密度が低下している が、これは群集の中に車椅子使用者のように遅い者が混在すると後 続に影響してばらつきが生じるためと考えられる。また、パターン 3 のように車椅子使用者が 2 人直列したとしても、通路がふさがれ ず健常者が追い越すことができる場合には、密度が低下する傾向に あることがわかる。

以上のことから、車椅子使用者が混在する群集の密度は、健常者 が追い越しができるかどうかで巽なり、それには車椅子の配置の影 響が大きいと考えられる。

\section{6 ネック通過時の通行量と群集密度の関係}

通行量 $N は$ 単位幅、単位時間あたりの通過人数を示す数值であ り、以下の式で表される。

$$
N=\rho \times v
$$

ここで、 $\rho$ は群集密度 $\left(人 / \mathrm{m}^{2}\right) 、 V$ は群集速度 $(\mathrm{m} / \mathrm{sec})$ を示す。 通行量 $N$ は群集密度 $\rho$ と群集速度 $V$ の積で表され、群集流の場合、 歩行速度は密度に依存し、密度が高いほど速度が低下する。そこ で最も単純なものとして、群集密度の上昇に対して、図 9 の破線 のように直線的に群集速度が低下する場合を考えてみると、群集 速度に密度を乘じた通行量は、 $\rho=0$ 又は $V=0$ のときに $N=0$ となるため、定性的には図 9 の曲線文9) のように表わされる。通行 量は当初群集密度の上:昇に伴い增加するが、最大値 $N_{\text {mas }}$ に達した 以降は逆に減少する注9)。

そこで、車椅子の数・配置の違いによるネック手前の群集密度注 8) と通行量の関係を表したものを図 10 に示す。これによると、通 行量は当初群集密度の上昇に伴い増加するが、車椅子使用者が先 頭に 2 人並列した場合 (パターン 4 ) 以外はその後低下する傾向が みられる。ここで、今回測定されたパターン $1,3,4$ につて、群集
密度 $\rho$ と通行量 $N$ の関係が 2 次関数で表されると仮定して回帰する と次式のとおりとなる（図10の曲線を参照）。なお、パターン 2 は 車椅子使用者が行列途中に 1 人混在しているが、測定された密度の 範囲が狭いこと、また、パターン 5 については車椅子が行列途中に 2 人並列したことで群集が割れたために、ここでは除外した。

$$
\begin{aligned}
N_{1}= & -7.273 \rho^{2}+24.011 \rho-18.112(1.4 \leqq \rho \leqq 1.8) \\
& \text { 重相関係数 : } \quad R_{1}{ }^{2}=0.960 \\
N_{3}= & -1.381 \rho^{2}+4.876 \rho-2.753(1.2 \leqq \rho \leqq 2.2) \\
& \text { 重相関係数 : } \quad R_{3}{ }^{2}=0.987 \\
N_{4}= & -1.143 \rho^{2}+5.243 \rho-4.393(1.6 \leqq \rho \leqq 2.3) \\
& \text { 重相関係数 : } \quad R_{4}{ }^{2}=1.000
\end{aligned}
$$

ここで、添字の $1 ， 3 ４$ は配置パターンを示す。

パターン 3 と 4 は、車椅子使用者の混在率は同じであるが、車 椅子の配置の違いにより、群集密度と通行量の変化は異なった特 性を示している。交通流の性質文泉としては、パターン 3 では重交 通の範囲までが表れ、パターン 4 では実測データを放物線で回帰 した場合、流動係数の最大值に達する程度以下の軽交通の範囲が 表れている。本来、車椅子が並列し通路がふさがれる場合 (パター ン4）のほうが重交通になり、ネックの通過時間が長くなると予 想されるが、表 1 に示すように、ネックの通過時間は、ネックの 位置に関係なくパターン 4 のほうが短くなった。そこで、パター ン 3 と 4 のネック通過時間について $\mathrm{t}$ 検定を実施したところ、有 意水準 0.05 で有意な差は認められなかった。

表 1 パターン 3,4 のネック通過時間（単位 : sec）

\begin{tabular}{|c|r|r|}
\hline & ケースB & \multicolumn{1}{|c|}{ ケースC } \\
\hline パターン3 & 15.54 & 13.36 \\
\hline パターン4 & 12.35 & 12.44 \\
\hline
\end{tabular}




\section{4. 考察}

\section{1 群集速度と群集密度の関係}

群集の歩行速度は密度の影響を強く受けると考えられ、群集密度 と歩行速度の関倸については、過去に様々な近似式が提案されてい る文6)。その中で、図 8 には健常者を対象とした戸川の近似式を重 ねているが、今回の実験では群集密度の上昇に伴い歩行速度が低下 するという顕著な傾向はみられなかった。これは、測定された密度 の範囲が狭いためであるが、全体としては戸川が示した関係に近い 結果となった。

一方、群集速度については、車椅子使用者によって通路がふさ がれない場合（パターン $1 \sim 3$ ） は、群集密度の上昇が抑制され るため、群集速度の低下が顕著に表れなかったと考えられる。こ れに対し、車椅子使用者によって通路がふさがれる場合（パター ン 4, 5) は、群集密度の上昇により歩行速度が低下すると予想 されるが、パターン 5 については、前述したように車椅子が行列途 中に 2 人並列したことで群集が割れたために、パターン $1 \sim 3$ に比 べて同程度以下となっている。また、車椅子使用者が先頭に並列し た場合 (パターン4）は、同じ混在率で直列した場合 (パターン 3 ) と比べて、群集密度が高いのに群集速度がほぼ同じであるのは、車 椅子使用者の歩行速度の違いによるものと推察される。パターン 4 は群集密度が明らかに高くなる配固形態であるが、図 5 に示すよう に車椅子使用者の歩行速度はパターン 3 よりも速くなっている。こ のため、パターン 4 では後続の健常者がそれに追随する形で全体的 に歩行速度が速くなったことからみて、車椅子使用者が混在する群 集の速度は、車椅子の配置だけでなく、車椅子使用者自体の歩行速 度の影響を強く受けると考えられる。

\section{2 車椅子使用者の配置が群集流に及ぼす影響}

パターン 4 のように、車椅子使用者によって通路がふさがれた 場合でも、ネック通過が遅滞しないという傾向は普遍的なもので はなく、車椅子使用者の特性により変化する可能性は否定できな い。このため避難計画においては、群集密度の上昇を極力抑える 方策を考える必要がある。まず、車椅子使用者が並列し、通路を ふさがないようにすることはいうまでもないが、車椅子使用者の混 在率が同じ 1 人で、その配置が異なる場合 (パターン 1 と 2 ) を比 較すると、図10に示すように、通行量は車椅子を行列途中に配置 したパターン 2 のほうが高くなっており、車椅子使用者が前方に位 置するほどネックでの通行量が低下する傾向にある。また、歩行速 度については、図 8 に示すように、車椅子の位置に関係なく顕著な 差はみられないことがわかる。

以上のことから、車椅子使用者は群集の後方で、通路の一方に 寄せるように誘導することにより、群集内の健常者に及ぼす影響 を抑えることができると考えられる。

\section{3 車椅子使用者が混在する群集の歩行速度}

1. 2項で述べたように、今回の実験では健常者による車椅子利用 を前提としており、単独で高秢者や病気の人などの車椅子利用が混 在した場合を包含したものではない。

従来、避難設計に用いられている健常者の歩行速度は、群集密度 が 1.5 人/ $\mathrm{m}^{2}$ 以下のとき $1.0 \mathrm{~m} / \mathrm{sec}$ 和8) である。今回の実験では、 健常者のみの群集速度は約 $1.2 \mathrm{~m} / \mathrm{sec}$ であったのに対し、車椅子 使用者が最大 $10 \%$ 混在した場合には約 $1.0 \mathrm{~m} / \mathrm{sec}$ となり、健常者
のみの群集に比べて群集速度は約 $20 \%$ 低下することがわかった。 ただし、車椅子使用者が最後尾にいた場合には、個人の体力によつ て遅れをとる可能性も皆無ではない。したがって、避難設計、上安全 側の評価を導くためには、車椅子使用者が混在する群集の速度は車 椅子使用者の単独歩行速度を考虑して定める必要がある。

なお、3.1 項で述べたように、今回の実験における車椅子使用者 の単独歩行速度の代表值を、志田等の考え方文川に従い、平均値の 下限から標準偏差を引いた值で表わすと $0.6 \mathrm{~m} / \mathrm{sec}$ となる。

\section{4 ネック通過時の流動係数}

建築計画において、廊下等の通路または扉を通る人数は与条件 としてわかっている場合が多いため、流動係数はその通過量を保 証する必要がある。図 9 のように、通行量は群集密度の影響を受 けるため、群集密度に条件を付けずに通行量を測定しても、吉田文 10)が指摘するように「通過した人数に基づく見かけの流動係数」と なり、通過能力としての流動係数にはならない。通行量は $d N / d$ $\rho=0$ のとき（図 9 の曲線の $N_{\text {aax }}$ のとき）に最大となり、これが、 通過能力としての流動倸数に相当するものであると考えられる。 したがって、避難設計に用いる流動係数は、図 9 の曲線の最大值 $N_{m a x}$ で定める必要がある。

今回の実験では、図10に示すように、パターン 1,3 では通行 量の最大值から重交通の範囲が表れ、パターン4についてはほほ 最大值に達すると考えられる軽交通の範囲が観測されている。ま た、前述したように、車椅子使用者の混在率が増えるほど群集流 の安定性が低下する傾向にあることがわかった。そこで、車椅子 使用者の混在率が同じ 2 人で、その配置が異なるパターン 3,4 を 比較すると、図 10 に示すように、車椅子使用者が 2 人直列した場 合 (パターン 3 ) は、図 9 の放物線に近い通行量の近似曲線が表れ ているが、車椅子使用者が 2 人並列した場合 (パターン 4 )につい ては重交通の範囲が表われていないために、通行量と密度の全体の 傾向を把握することはできない。また、パターン 3 は車椅子使用者 によって通路がふさがれないため、実際の避難行動でも十分起こり える形態であり、前述したように、パターン 3 と 4 のネック通過時 間に有意な差も認められなかった。

以上の考察から、本論文ではパターン 3 から流動係数を推定す る。図 10 の近似曲線より、群集密度が 1.8 人 $/ \mathrm{m}^{2}$ のさきに通行量 は最大となり、流動係数は前述の回帰式から 1.54 人 $/ \mathrm{m} / \mathrm{sec}$ とな る。これに対して、従来、避難設計に用いられている流動係数は 1.5 人 $/ \mathrm{m} / \mathrm{sec}$ 文718 であるからら、車椅子使用者の混在率が $10 \%$ までの 群集におけるネック通過時の流動係数は、健常者のみの群集に関す る慣用值に比べて低下しないと考えられる。

\section{5. まとめ}

今回の奏験を通じて、健常者による車椅子利用が混在する群集の 流動特性を把握し、群集速度、流動係数等の数値を示した。主な知 見は以下のとおりである。

1) 車椅子使用者が混在する群集では、車椅子使用者の歩行速度は単 独歩行に比べてほとんど低下しない。

2) 車椅子使用者が混在する群集步行尖験において、避難設計.上有効 な歩行速度を得るためには、健常者の列では 6 行以上配置する必 要がある。 
3) 車椅子使用者が混在する群集の密度は、車椅子の配置の影響を強 く受ける。

4) 群集行動への影響は、ネックの位置よりも車椅子の配置のほうが 大きい。

5) 車椅子使用者が $10 \%$ 混在する群集の速度は、健常者のみの群集 に比べて約 $20 \%$ 低下するが、避難設計上安全側の評価を導くため には、群集速度は車椅子使用者の単独歩行速度を考慮して定める必 要がある。

6) 車椅子使用者が $10 \%$ 混在する群集におけるネック通過時の流動 係数は、従来避難設計で用いられていた健常者のみの群集に関する 慣用值に比べて低下しない。

なお、 4.3 項で述べたように、今回の実験における車椅子使用者 の単独歩行速度の代表値を、平均値の下限から標準偏差を引いた値 で表わすと $0.6 \mathrm{~m} / \mathrm{sec}$ となる。また、車椅子使用者が後方にいて 遅れをとった場合には、車椅子使用者の単独歩行速度によって群集 速度が規定される可能性もある。したがって、上記 1)〜6)の群集 に混在する車椅子使用者は、 $0.6 \mathrm{~m} / \mathrm{sec}$ 以上の歩行速度で避難でき ることが前提となる。

'今回は、健常者による車椅子利用の自力歩行を前提としたが、車 椅子使用者が公共の建築空間を利用する際には、身障者や高路者 の車椅子利用、介助者が付き添う場合など多様な状態が存在する。 また、奏際の避難経路は直線ばかりでなく曲がりもあり、車椅子 へ及ぼす影響が皆無とはいえない。これらの点を踏まえ、今後は、 実際の身障者, 高齢者との比較、群集内の健常者が車椅子使用者 を介助した場合の群集の流動特性、経路途中の曲がりの影響など についても実測を行い、自力歩行との比較検討を行うことで、避 難設計に用いるデータとしての有効性を明らかにしてゆきたい。

\section{謝辞}

本研究を奏施するにあたり、奏験に協力して頂きました早稲田大 学理工学部建築学科2001，2002年度の 2 年生の受講生並びに早稲田 大学長谷見研究室の上川大輔氏、大西卓氏、峯岸良和氏、有村亮氏、 渥美良紀氏、榉原攝雄氏、大山有紀子氏、柿木英治氏及び松尾祐介 氏に厚く御礼申し上げます。また、本研究の一部は平成 14 年度科 学研究費補助金 (萌芽研究, 課題番号 14655208), 「高齢者疑似体 験用具を使用した高齢者の避難行動特性の定量化の手法」の補助を 受けて行われた。ここに謝意を表します。

\section{注}

1) 2001,2002 年度において、早秒田大学理工学部建築学科の 2 年生を対象 とした授業であり、履修する学生 50 数人を 20 名程度の 3 グループに分け、 各グループごとに(1)単独歩行実験、(2)群集步行実験、(3)車椅子等の利用体験 の 3 種類を 3 回の授業に分けて行った。また、天候等の理由により(2)と(3)を 入れ替えることはあったが、(2)を行う前に必ず(1)を終わらせるようにした。 なお、授業でば車椅子実験だけでなく、高齢者疑似体験用具を用いた実験も 行っている。

2) 制マキテック製 KI-10（幅；車輸外侧で $60 \mathrm{~cm}$ ，奥行き； $100 \mathrm{~cm}$ )

3) 幅約 $50 \mathrm{~cm}$ 、高さ約 $120 \mathrm{~cm}$ のスチール製揭示板二つを障害物とし、幅員 1 mのネックを形成した。

4) 一般に群集流になると、遅い歩速の人に同調して全体が遅くなるといわれ ており文、当然前列よりも後列のほうが步行速度は遅くなるが、ある位置 からは周りとの同調により一定の速度に収束していくと考えられる。また 群集における前列の健常者は、通常周りの影響を受けずに歩行することが可
能であり、各被験者の平均値で検討しても、群集全体の歩行速度の傾向を示 すことができないこと、及び避難計画上は安全側の設計を誘導することから 最後尾の歩行速度を群集速度と定義した。

5) 吉田文101は、流動係数には「通過した人数に基づく見かけ上の流動係数」

と「通過可能な人数に基づく流動係数」という二つの概念があることを導い たが、戸川文かが定めたのは「通過可能な人数に基づく流動係数」であると 指摘しており、本論文ではこれを流動係数と定義した。

6) 2001,2002 年度の被験者数の合計である。男女比は 4:1で男性のほう が多く、全ての被験者の健康状態は良好であり、実験に影響を及ほす身体的 障害はなかった。

7) 図 3 に示す箱ひげ図において、上側ヒンジとは、最大値と中央値の間に位 置する値で、全デー夕の $75 \%$ がその值より小さくなるところである。また、 下側ヒンジとは、最小值と中央値の間に位置する值で、全データの $25 \%$ その値より小さくなるところである。上側ヒンジと下側ヒンジの差は四分位 偏差と呼ばれ、ばらつきの大きさを示す指標として用いることができる。統 計学では、上側ヒンジと下側ヒンジからそれぞれ四分位偏差の 1.5 倍のとこ ろを上内境界点, 下内境界点といい、上内境界点より大きいデー夕、または 下内境界点より小さいデー夕は外机值として除去する。ただし、最大值が上 内境界点より小さい場合、あるいは最小值が下内境界点より大きい場合は、 それぞれ最大値を上内境界点、最小值を下内境界点とする。

8) ネック手前の画像データを基に、先頭が撮影区間に到着後 1 秒間隔で $5 \mathrm{~m}^{2}$ $(2 \mathrm{~m} \times 2.5 \mathrm{~m})$ の範囲内にいる人数を計測し、その中の最大值を群集密度 とした。

9) 文 9)では、流動係数の最大値 $N_{m a x}$ を境にして傾きが正の範囲を「軽交 通」、傾きが負の範囲を「重交通」として区別している。

\section{参考文献}

1)戸川喜久二：群旅流の観测に基づく避難施設の研究，建築研究報告, N0. $14,1955.2$

2) 植竹徹, 渡部学, 奈良松範: 出入口および階段降り口における群集の流動 係数について, 火災, Vol. 44. №1-2, pp. 1 7, 1996

3）奈良松䇩, 大島泰伸, 渡部学: 避難時の群集歩行速度について, 階段にお ける步行，火災，Vol. 45. №1-2，pp. 11～17，1996

4) 志田弘二, 辻本誠: 病院患者の避難時運動能力, 火災, V01. 35. №6, pp. $27 \sim 32,1985$

5) 厚生省病院管理研究所：災害に対する病院の保安避難体制に関する研究 (中間報告書)，1975. 3

6) 新建築学体系 12 建築安全論, 彰国社, 1983

7）(財) 日本建築センター：新・建築防災計画指針，1995

8) 建築学体系 21 建築防火論, 彰国社, 1973

9) Richard Haberman 著, 中井喗久 訳: 交通流の数学モデル, 現代数学社, 1981

10) 吉田克之：建築設計における避難行動予測に関する研究，早稲田大学学 位論文, 1991

\section{本論文に関連する既発表論文}

1) 土屋伸一, 古川容子, 宮野義康, 吉田直之, 長谷見雄二：群集歩行行動 における高齢者・身体障害者の影響（その 4）東椅子使用者を含む群集の 流動特性, 日本建築学会関東支部研究報告集 I, pp. $425 \sim 428,2002.3$ 2) 土屋伸…, 古川容子, 宮野義康, 吉田直之, 長谷見雄 $\cdots$ : 群集歩行行動 における高齢者・身体障害者の影響（その4）東椅子使用者を含む群集流 動特性, 日本建築学会大会学術講演梗概集 A-2 分冊, pp. 165 168, 2002. 8 